\title{
TECHNOLOGICAL SOLUTIONS TO ENCOURAGE CIVIC ENGAGEMENT IN URBAN PLANNING: EXPERTS' PERSPECTIVES
}

\author{
Anika KAPOOR ${ }^{1}$ \\ Devendra Pratap SINGH ${ }^{2}$ \\ DOI: https://doi.org/10.35782/JCPP.2021.4.0픈
}

\begin{abstract}
The smart city concept is primarily grounded on the use of technology to provide robust solutions to the complex urban problems and endorse sustainable development practices to enhance the citizen's quality of life. The use of technology for citizen participation is indispensable for effective city planning, especially at the local level. The study attempts to identify notions regarding a technological approach to city planning in the form of variables through literature and eventually categorize them as catalysts and burdles for the eloquent participatory city planning. The study is based on a primary survey with city planning experts. The adaptability of the identified variables is assessed through the perception of the experts, weighed on the five-point Likert scale. The findings intend to facilitate policy makers and practitioners in highlighting the use of technology in a city planning framework.
\end{abstract}

Keywords: technology, public participation, urban planning, Local Area Plan (LAP)

\section{Introduction}

Urban population is increasing at the unprecedented rate and causing urban management concerns for the local development authorities. The smart city concept has emerged as a solution and has been drawing attention of experts and planners. Nonetheless, the research reveals that the smart cities approach has not been able to yield desired outcomes in the absence of smart communities (Satterthwaite, 1986).

Technology can easily enable connections between community and government to provide practical solutions to the urban local problems and to improve the quality of life of the citizens (Knight Frank, 2012). This idea has been researched and there have

1 Research Scholar, Amity School of Architecture and Planning, Amity University, Noida, Uttar Pradesh, India, e-mail: anikakapoor1985@gmail.com

2 Professor and Head, Amity School of Architecture and Planning, Amity University, Noida, Uttar Pradesh, India, e-mail: dpsingh@amity.edu 
been efforts to involve local people while planning for urban areas, especially in the developed world. There have been various approaches associated with the concept of public participation for urban development. The research shows that the consumerist approach is the most accepted and used approach to involve people in decision making. It refers to a method where people write complaints and suggestions to the development authorities and seek resolutions to problems. (Lowdnes, Pratchett and Stroker, 2001). Most of the development authorities in the world still prefer the focus group approach to seek public opinion in planning related matters and very few use consultative innovations (Lane, 2005). Few technological interventions have been used to enhance public participation for planning and decision making (Krishnaswamy, 2012).

The Government of India also realized the need to include local people as partners in the planning and development of urban areas. In 1992, the Indian parliament passed the Constitutional Amendment Act 74, which promulgated the approach to public participation and local self- governance in India. The act stressed upon the selfsufficiency and self-dependency of the Urban Local Bodies (ULBs) in urban India. Through this act, it was envisaged that people would participate in budgeting, planning, land use, zoning issues etc. This should have led to transparency, accountability and wider civic participation, that would have strengthened urban governance in municipal bodies of the country. Few of the states in India that demonstrated the positive impact of a participatory approach to planning include Kerela, Maharashtra, Karnataka, and West Bengal (Harriss, 2010). Despite the success, the majority of ULBs in Indian states have not adopted this approach in its true spirit (Leena and Sharma, 2007). In India, there are not many success stories of participatory planning. The succeeding paragraph summarizes the instances of efforts for a paradigm change to a bottom-up approach instead of a traditional top-down approach in planning. Until now, Delhi is the only Indian state to pioneer the concept of local area planning.

The Indo-USAID (FIRE-D) project was launched in 2005 with the objective to reformulate the building byelaws and to prepare draft guidelines to prepare Local Area Plans in Delhi. Based on the draft, the Delhi Development Authority tested the guidelines with the Municipal Corporation of Delhi in five diverse areas of the city, and then revised guidelines for LAP were made in 2008. Simultaneously, the Masterplan of Delhi 2021 was under preparation by the Delhi Development Authority in 2007. It is the first Masterplan of the city to describe the concept of decentralized local area planning by participatory approach. It defines the local area plan as a plan of a small area (electoral ward/or planning subzone) to be prepared and approved by the local body. The Masterplan also states that special guidelines shall be formulated by a technical committee for sanctioning the local area plan in Delhi. 2012 was marked as a year in the planning history of Delhi and based on provisions in the Masterplan of Delhi 2021 and on LAP guidelines, 33 wards out of 272 were selected in the first phase to prepare local area plans. The Mumbai Municipal Corporation also initiated the process of local area planning in 2013 but the idea was dropped in 2016. Also, the Local Area Plans for 33 wards in Delhi were not approved and the entire process halted in the absence of a statutory framework. Despite of all these efforts, no Local Area Plan 
(a statutory document) has been approved and implemented in any city of India till date.

Though the Ministry of Urban Development reiterated the relevance of Local Area Plans in the URDPFI Guidelines and the Delhi Development Authority in its Unified Building Bye Laws for Delhi, nothing seems to be working in this regard. This certainly seeks technological solutions to promote public participation in urban planning mechanisms. Therefore, the study identifies technological indicators (Bryant and Yarnold, 1995) that in the form of variables through literature and eventually categorize them as catalysts and hurdles for the eloquent participatory city planning. The study is based on the perception of experts of urban planning, especially with respect to planning of local areas in Delhi.

\section{Literature Review}

Technological interventions are vital to enhance public participation in decision-making, but research indicates that such interventions should complement the existing traditional approach and tools of participation instead of completely replacing them (Kingston, Carver, Evans, and Turton, 2000; Li, Chang and Yi, 2004). Nonetheless, there are few areas in which technology seems to be the only solution. The mapping of urban areas has always been an issue of concerns for planners, policy-makers and also for residents. Geographical Information Systems have emerged as efficient mapping tools in recent years. This technology helps in connecting spatial information with socio-economic information, providing a base for effective inclusive planning, especially at local level. Technology seems to be easily available, affordable, and accessible in developed economies (Warner, 2015). There is literature to support the fact that web-based technology is a world-wide accepted mechanism for information dissemination, and a medium for partnership and communication between people and government (Wang and Bryer, 2013). Moreover, research suggests that web-based technologies are an affordable and accessible way to encourage public participation and can be easily adopted by general masses (Herranz, Romero-Gómez, Díaz, and Onorati, 2014).

At the same time, hurdles in adoption of technology have been reported, especially in developing countries, where governments are often biased towards the rich and educated (Bailey and Grossardt, 2010). Based on past experiences, people expressed that they are not consulted for planning at local areas (Enshassi and Kullab, 2014). It is also reported that if given the opportunity, IT illiteracy amongst people may discourage them to accept technology as a tool for participation in decision making (Jankowski and Nyerges, 2003; Kingston, 2002; Li et al., 2004). Moreover, since technology has not been formally used for public participation for planning procedures in India (Menon and Hartz-Karp, 2019), people perceive the adoption of technology as a behavioral and not as a logistic issue. This has been restated in many research articles (Abels, 2007; Hennen, 2002; Macintosh, 2004; Mashelkar, 2008). IT literacy is key to adopting technology, which then allows institutions or organizations to reach more people, according to literature (Roşca, 2015; Shekgola, Maluleka, and Rodrigues, 2021). Therefore, urban residents seem to be more participative in local, smart city affairs, than rural residents. 
ULBs need to promote and enhance the use of technology as a means for public participation through the use of smartphones (Metallo, Gesuele, Guillamón, and Ríos, 2020; Milakovich, 2010; Oh, Jeong and Shin, 2019; Wang and Bryer, 2013) and appbased technology laptops (Díaz, Carroll and Aedo, 2016; Goodchild, 2007; Hennen, 2002; Herranz et al., 2014; Kingston et al., 2000; Li and Ma, 2006)as well as capacitate ULBs through training programs (Nallathiga, 2014) to further be able to enhance ability of the users to use and adopt technology for participation in decision making. Therefore, ULBs shall use web-based and phone-based technologies to reach out to a broader audience of citizens for suggestions (Bifulco, Tregua, Amitrano, and D'Auria, 2016; Ham, Teng, Wijaya, and Wikopratama, 2018). This shall enhance the efficiency of the urban governance.

The literature review has led to the identification of various technology related attributes that are pertinent while making Local Area Plans or other participatory plans in different developing countries. Based on the literature review and the pilot study, ten variables were chosen for the study in Delhi. The indicators identified from the literature are further categorized as catalysts and hurdles:

\section{Catalysts (C)}

1) People prefer the complaint and suggestion method, as a tool for public participation in decision making;

2) People prefer postal questionnaires, public meetings and personal interviews over web based technological interactions;

3) People are IT literate and willing to connect through easily available web-based tools for participating in decision making;

4) Technology can facilitate database creation at micro level;

5) Technology can enable coordination among various governmental departments;

6) Technology will augment efficiency, accountability and transparency of the Government offices.

\section{Hurdles (H)}

7) People do not adopt technology as many of them are IT illiterate;

8) Technology is a costly intervention in the government affairs;

9) Technology is not easily accessible to the common man;

10) Behavioral issues discourage people to adopt technology. 
38 | Technological solutions to encourage civic engagement in urban planning

\section{Methodology}

A qualitative study is considered most suitable when the research is based on the perception of people (Stake, 2010), such as this study, which is based on perceptions of experts about the technological variables and their significance in local area planning in India. The identified variables were converted into a questionnaire which was used for data collection. A five-point ordinal Likert scale was used to measure the responses. 100 planning experts were surveyed, a sample size deliberated as sufficient while conducting research (Green, 1991). The experts consisted of practicing urban planners, allied academicians, officials of the Development Authority and Municipal Corporations, MIS (Management information system) \& GIS scholars, and veterans of the related fields and subjects. Snowball sampling or chain-referral sampling technique was used to choose the sample respondents. Officials of the Municipal Corporation of Delhi and of the Delhi Development Authority were surveyed, as well as experts working in institutes such as All India Institute of Local Self-Government, Participatory Research in Asia, the International Council for Local Environmental Initiatives, the School of Planning and Architecture in New Delhi, INTACH, Jamia Millia Islamia University, Indraprastha University or the Association of Municipal Corporations and Development Authorities. As a limitation, there existed the fear of sampling bias since the initial samples tend to suggest people that they know as samples for the study. The distribution of the sample is demonstrated in Figure 1.

\section{Figure 1: Composition of Expert Sample Respondents}

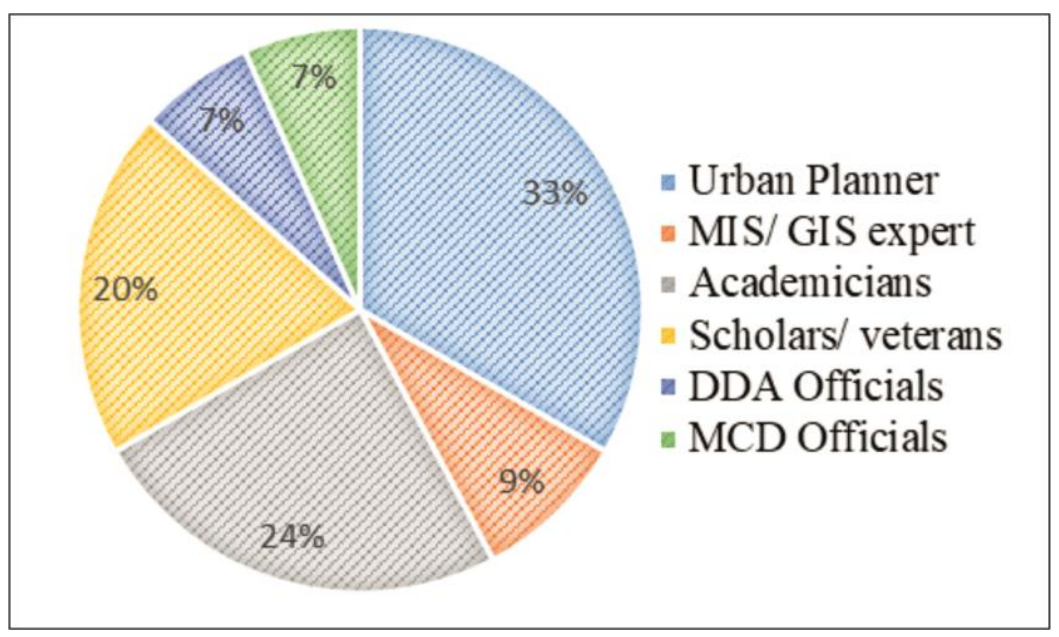

Source: Author's own representation 


\section{Analysis and Findings}

The data analysis started with the critical understanding of the data characteristics. Descriptive statistics (mode, mean, standard deviation and error) were conducted and verified. An attempt was made to assess the normality of the dataset created for experts. Table 1 presents the descriptive statistics. The mean of each question indicates the perception of the experts. Experts largely disagreed with the variables identified as hurdles and supported technology as a catalyst for successful local area planning.

Table 1: Descriptive Statistics of Experts

\begin{tabular}{|l|c|c|c|c|}
\hline \multicolumn{1}{|c|}{ Technological Indicators } & mean & mode & StDev & StErr \\
\hline $\begin{array}{l}\text { People prefer the complaint and suggestion method, } \\
\text { as a tool for public participation in decision making. }\end{array}$ & 2.11 & 2 & 1.1 & 0.2 \\
\hline $\begin{array}{l}\text { People prefer postal questionnaires, public meetings } \\
\text { and personal interviews over web based technological } \\
\text { interactions. }\end{array}$ & 2.20 & 2 & 1.1 & 0.2 \\
\hline $\begin{array}{l}\text { People are IT literate and willing to connect through } \\
\text { easily available web-based tools for participating in } \\
\text { decision making. }\end{array}$ & 4.13 & 4 & 0.9 & 0.1 \\
\hline $\begin{array}{l}\text { Technology can facilitate database creation at micro } \\
\text { level. }\end{array}$ & 4.29 & 4 & 0.7 & 0.1 \\
\hline $\begin{array}{l}\text { Technology can enable coordination among various } \\
\text { governmental departments. }\end{array}$ & 4.20 & 4 & 0.8 & 0.1 \\
\hline $\begin{array}{l}\text { Technology will augment efficiency, accountability } \\
\text { and transparency of the Government offices. }\end{array}$ & 4.31 & 4 & 0.7 & 0.1 \\
\hline $\begin{array}{l}\text { People do not adopt technology as many of them are } \\
\text { IT illiterate. }\end{array}$ & 1.84 & 2 & 1.0 & 0.2 \\
\hline $\begin{array}{l}\text { Technology is a costly intervention in the government } \\
\text { affairs. }\end{array}$ & 2.11 & 2 & 1.1 & 0.2 \\
\hline $\begin{array}{l}\text { Technology is not easily accessible to the common } \\
\text { man. }\end{array}$ & 2.13 & 2 & 1.1 & 0.2 \\
\hline $\begin{array}{l}\text { Behavioral issues discourage people to adopt } \\
\text { technology. }\end{array}$ & 1.84 & 2 & 1.0 & 0.2 \\
\hline
\end{tabular}

Source: Author's compilation

The viewpoint of the experts is crucial to understand if the government officials are also well capacitated to adopt technology for participatory planning at local level. In the existing framework, the traditional method of complaints and suggestions is not the most implemented tool of public involvement and people are ready to adopt technology for public participation. People access technology largely through their smartphones (Rossca, 2018). Therefore, the majority of experts thinks that the illiteracy of the general public with respect to technology is not the reason for not adopting the technology. According to them, technology is not used for public consultation and planning due to behavioral issues. 
40 | Technological solutions to encourage civic engagement in urban planning

According to the experts, adopting technology for public participation is affordable. Moreover, it is easily accessible to all classes of society. They believe that technology will facilitate coordination among different departments and organizations and will enhance transparency and accountability. The majority of experts think that technology (GIS) will increase the efficiency of ULBs.

The results from the descriptive analysis have been validated by Principal Component Analysis (PCA). The sampling appropriateness can be measured by examining the Kaiser-Meyer-Olkin (KMO) (Hair, Anderson, Tatham, and Black, 1995; Kaiser, 1970). Results showed that the PCA is valid (Ulanowicz, 1986). Therefore, it is an appropriate technique for further analysis of data. Table 2 shows the eigenvalues of the attributes.

Table 2: Eigenvalues of selected attributes

\begin{tabular}{|c|c|c|c|c|c|c|c|c|}
\hline \multicolumn{9}{|c|}{ Total Variance Explained } \\
\hline \multicolumn{3}{|c|}{ Initial Eigenvalues } & \multicolumn{3}{|c|}{$\begin{array}{l}\text { Extraction Sums of Squared } \\
\text { Loadings }\end{array}$} & \multicolumn{3}{|c|}{$\begin{array}{c}\text { Rotation Sums of Squared } \\
\text { Loadings }\end{array}$} \\
\hline 혼 & 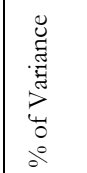 & 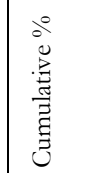 & 혼 & 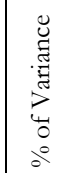 & 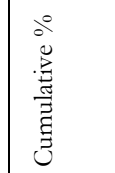 & 푱 & 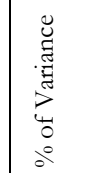 & 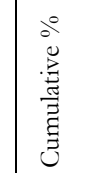 \\
\hline 3.026 & 27.507 & 27.507 & 3.026 & 27.507 & 27.507 & 2.878 & 26.168 & 26.168 \\
\hline 2.497 & 22.703 & 50.209 & 2.497 & 22.703 & 50.209 & 2.558 & 23.258 & 49.426 \\
\hline 1.408 & 12.799 & 63.009 & 1.408 & 12.799 & 63.009 & 1.473 & 13.393 & 62.819 \\
\hline 1.084 & 9.852 & 72.861 & 1.084 & 9.852 & 72.861 & 1.105 & 10.041 & 72.861 \\
\hline 829 & 7.533 & 80.393 & & & & & & \\
\hline 643 & 5.845 & 86.238 & & & & & & \\
\hline 543 & 4.935 & 91.173 & & & & & & \\
\hline 486 & 4.418 & 95.591 & & & & & & \\
\hline 256 & 2.331 & 97.922 & & & & & & \\
\hline 212 & 1.923 & 99.845 & & & & & & \\
\hline 017 & .155 & 100.000 & & & & & & \\
\hline
\end{tabular}

The PCA yielded four factors by merging the appropriate attributes. The first factor has the maximum variance and therefore has the highest eigenvalues. The following factor accounts for the leftover variance. Attributes with factor loadings greater than 0.5 have only been considered for the groupings. In this study, the first 4 factors explain $72.861 \%$ of variance. This has been shown in the scree plot (Figure 2). 


\section{Figure 2: Scree Plot for Technology Indicators: Perception of Experts}

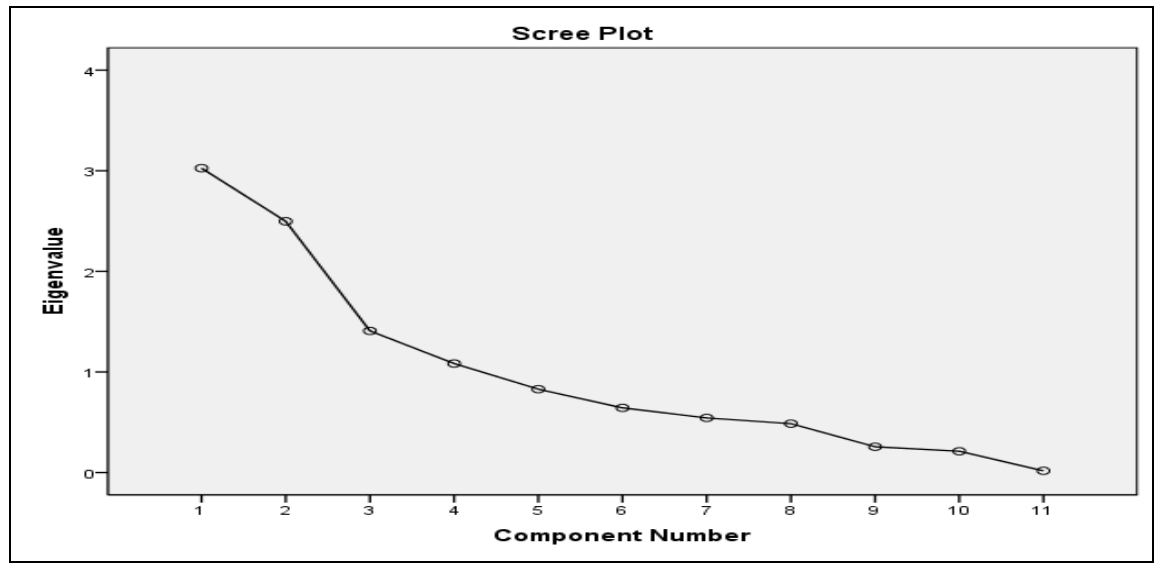

Source: Author's own representation

Table 3 demonstrates the rotated factor loadings demonstrating and correlations between the variables. This table helped in clubbing of the variables to identify the final factors.

Table 3: Rotated Component Matrix of selected attributes

\begin{tabular}{|c|c|c|c|c|c|}
\hline \multirow{2}{*}{ Codes } & \multirow{2}{*}{ Rotated Component Matrix } & \multicolumn{4}{|c|}{ Component } \\
\hline & & 1 & 2 & 3 & 4 \\
\hline C_1 & $\begin{array}{l}\text { People prefer the complaint and suggestion method, as a tool for } \\
\text { public participation in decision making. }\end{array}$ & .775 & 240 & .338 & .064 \\
\hline C_2 & $\begin{array}{l}\text { People prefer postal questionnaires, public meetings and personal } \\
\text { interviews over web based technological interactions. }\end{array}$ & .613 & -403 & .478 & .063 \\
\hline C_3 & $\begin{array}{l}\text { People are IT literate and willing to connect through easily available } \\
\text { web-based tools for participating in decision making. }\end{array}$ & .840 & .358 & 290 & .032 \\
\hline H_1 & People do not adopt technology as many of them are IT illiterate. & .137 & .080 & .668 & .169 \\
\hline H_2 & Technology is a costly intervention in the government affairs. & .443 & .250 & .563 & 243 \\
\hline H_3 & Technology is not easily accessible to the common man. & .837 & 311 & .335 & .002 \\
\hline H_4 & Behavioral issues discourage people to adopt technology. & .009 & .034 & .263 & .916 \\
\hline C_4 & Technology can facilitate database creation at micro level. & .182 & 668 & .041 & .161 \\
\hline C_5 & $\begin{array}{l}\text { Technology can enable coordination among various governmental } \\
\text { departments }\end{array}$ & .337 & .760 & .083 & .180 \\
\hline C_6 & $\begin{array}{l}\text { Technology will augment efficiency, accountability and transparency } \\
\text { of the Government offices. }\end{array}$ & .375 & .613 & .137 & .175 \\
\hline
\end{tabular}


42 | Technological solutions to encourage civic engagement in urban planning

The factors are congregated and each group of factors is named to represent the grouped factor. 4 factors explain the variance in performance of the variables as shown in Table 4 . There are two catalyst and two hurdle factors for implementable Local Area Plans.

Table 4: Identified Significant Factors

\begin{tabular}{|c|c|c|}
\hline Factors & Variable included & Description of the factor \\
\hline C1 & $\begin{array}{l}\text { - People prefer the complaint and } \\
\text { suggestion method, as a tool for public } \\
\text { participation in decision making. } \\
\text { - People prefer postal questionnaires, } \\
\text { public meetings and personal interviews } \\
\text { over web based technological } \\
\text { interactions. } \\
\text { - People are IT literate and willing to } \\
\text { connect through easily available web- } \\
\text { based tools for participating in decision } \\
\text { making. } \\
\text { - Technology is not easily accessible to the } \\
\text { common man. }\end{array}$ & $\begin{array}{l}\text { Public consultation to be } \\
\text { promoted using conventional } \\
\text { methods along with } \\
\text { technological interventions as } \\
\text { the officials are ready to adopt } \\
\text { the technology. }\end{array}$ \\
\hline $\mathrm{C} 2$ & $\begin{array}{l}\text { - Technology can facilitate database } \\
\text { creation at micro level. } \\
\text { - Technology can enable coordination } \\
\text { among various governmental } \\
\text { departments. } \\
\text { - Technology will augment efficiency, } \\
\text { accountability and transparency of the } \\
\text { Government offices. }\end{array}$ & $\begin{array}{l}\text { Technology should be used to } \\
\text { create databases, to coordinate } \\
\text { among different departments, } \\
\text { to enhance transparency and } \\
\text { therefore increase efficiency of } \\
\text { the urban local bodies. }\end{array}$ \\
\hline H1 & $\begin{array}{l}\text { - People do not adopt technology as many } \\
\text { of them are IT illiterate. }\end{array}$ & $\begin{array}{l}\text { IT literacy of the masses and of } \\
\text { officials should be promoted to } \\
\text { encourage them to adopt the } \\
\text { technology for public } \\
\text { participation. }\end{array}$ \\
\hline $\mathrm{H} 2$ & $\begin{array}{l}\text { - Behavioral issues discourage people to } \\
\text { adopt technology. }\end{array}$ & $\begin{array}{l}\text { Creating institutional } \\
\text { arrangements in policy to gain } \\
\text { people's trust for public } \\
\text { involvement in decision } \\
\text { making. }\end{array}$ \\
\hline
\end{tabular}

Source: Compiled by the Authors

\section{Discussions}

The use of geographic information system (GIS) technology to enhance efficiency and coordination and real-time data updating is reported to be the most critical catalyst, identified by experts. This factor indicates that technology can facilitate coordination 
among different departments and organizations (Duncan and Moriarty, 1998) and can increase the efficiency of the ULBs to use social media, mobility, analytics and cloudbased technologies in governance (Yavetz and Aharony, 2020). The future of governance might well lie in the Internet of Things (IoT), a tool towards transparent and accountable governance (Malhotra, 2016). This has led to the advent of Information and Communications Technology (ICT) as policy priority to enable reforms in local governance. Despite this, some areas seek intervention, including that in ULBs (Cordella and Iannacci, 2010; Heeks, 2002). The technology-led driver (i.e. "Use of appropriate ICT tools to facilitate E-Governance") is yielded from the discussion with the experts.

The driver refers to the ICT-supported local level governance. Numerous studies claim that e-governance is a new approach and is widely accepted as a tool for interaction between governments and citizens (Cegarra-Navarro, Garcia-Perez and Moreno-Cegarra, 2014). It was realized that ICT can dramatically help in enhancing accountability, transparency and efficiency of the ULBs (Cordella and Iannacci, 2010). This shall also give impetus to the participatory approach to planning. People tend to comment on what they see or perceive. There has to be a system that allows its users to vote for their preferences. It is perceived that visual information is easier to understand and react upon (Krishnaswamy, 2012).

1. GIS shall be adopted by ULBs to create, maintain and update real-time databases (Goodchild, 2010; Li, Batty and Goodchild, 2020; Lu, 2009);

2. At the same time, modeling software shall be used to generate an interactive smartphone-based application which will allow access to the easily interpretable visual information, since smartphones are becoming an increasingly used platform for augmenting realities (Castells, 2009; Goodchild, 2020; Rowe and Frewer, 2000). Such a system where people can visualize proposed urban developments or can give feedback to the government would give people the ability to participate in planning decisions in their own time, without attending any meetings or presentations (Wimmer, Grimm, Jahn, and Hampe, 2013);

3. The public participation system shall be linked to many daily used sites as a required field. The satisfaction level of the people can be assessed through close-ended questions. This can further be linked with a tax exemption or any other incentive that should be given to a conscious and responsible citizen. Such innovations would lead to increased public participation and thereby ensuring transparent and accountable governance.

The concept of E- participation is found to be acceptable by the majority of the stakeholders in different economic strata and age groups. It has been evident that people now can locate themselves on a map, especially while booking cabs. This implies that it is more important to be technology-literate than just simply literate to participate through smartphone app-based in public consultations on the planning process. Therefore, ICT tools shall be encouraged to enhance E-governance at the local level. 
44 | Technological solutions to encourage civic engagement in urban planning

\section{Conclusions}

This paper aimed to investigate the technological attributes that can enhance the efficacy of local area planning. Ten indicators were recognized from literature. Subsequently, each hurdle and catalyst was tested for its adaptability in the context of local area planning in Delhi through the perception analysis of the identified experts. The use of GIS technology to enhance efficiency and coordination and real-time data updating is reported to be the most critical catalyst. This article might also be useful for policy makers and practitioners to define adaptable local area planning frameworks. This work can be extended to examine the perception of users in Delhi and its adjoining cities with respect to the identified indicators.

\section{Authorship}

The authors contributed equally to the research. Dr. Devendra Pratap Singh helped in conceptualization and framing the objectives and provided overall supervision.

\section{Acknowledgements}

This study is supported by Amity School of Architecture and Planning, Amity University, Noida, Uttar Pradesh, India. We are grateful to Dr. Ekta Singh for her support and guidance.

\section{Funding}

The author(s) received no financial support for the research, authorship, and/or publication of this article.

\section{Declaration of conflicting interests}

The author declares no conflicting interests.

\section{References}

Abels, G. (2007). Citizen involvement in public policy-making: Does it improve democratic legitimacy and accountability? The case of pTA. Interdisciplinary Information Sciences, 13(1), 103-116.

Bailey, K., \& Grossardt, T. (2010). Toward structured public involvement: Justice, geography and collaborative geospatial/geovisual decision support systems. Annals of the Association of American Geographers, 100(1), 57-86.

Bifulco, F., Tregua, M., Amitrano, C. C., \& D’Auria, A. (2016). ICT and sustainability in smart cities management. International Journal of Public Sector Management, 29(2), 132-147.

Bryant, F.B., \& Yarnold, P.R. (1995). Principal-components analysis and exploratory and confirmatory factor analysis. In: L. G. Grimm \& P. R. Yarnold (Eds.), Reading and 
understanding multivariate statistics. Washington DC: American Psychological Association (99-136).

Castells, M. (2009) Communication Power. New York: Oxford University Press.

Cegarra-Navarro, J. G., Garcia-Perez, A., \& Moreno-Cegarra, J. L. (2014). Technology knowledge and governance: Empowering citizen engagement and participation. Government Information Quarterly, 31(4), 660-668.

Cordella, A., \& Iannacci, F. (2010). Information systems in the public sector: The eGovernment enactment framework. The Journal of Strategic Information Systems, 19(1), 52-66.

Díaz, P., Carroll, J. M., \& Aedo, I. (2016). Coproduction as an approach to technologymediated citizen participation in emergency management. Future Internet, 8(3), 41.

Duncan, T., \& Moriarty, S. E. (1998). A communication-based marketing model for managing relationships. Journal of Marketing, 62(2), 1-13.

Enshassi, A., \& Kullab, A. S. (2014). Community participation in local governments: public consulting and transparency in Gaza Strip, Palestine. International Journal of Sustainable Construction Engineering and Technology, 5(1), 9-21.

Goodchild, M. F. (2007). Citizens as sensors: the world of volunteered geography. GeoJournal, 69(4), 211-221.

Goodchild, M. (2010). Twenty years of progress: GIScience in 2010. Journal of Spatial Information Science, (1), 3-20.

Goodchild, M. F. (2020). How well do we really know the world? Uncertainty in GIScience. Journal of Spatial Information Science, (20), 97-102.

Government of India (2012). Framework for Citizen Engagement in e-Governance. India: Ministry of Communications \& Information Technology, Department of Information Technology.

Green, S. B. (1991). How many subjects does it take to do a regression analysis. Multivariate Behavioral Research, 26(3), 499-510.

Hair, J. F., Anderson, R. E., Tatham, R. L., \& Black, W. C. (1995). Multivariate data analysis. Englewood Cliffs, NJ: Prentice-Hall.

Ham, H., Teng, M. A., Wijaya, E., \& Wikopratama, R. A. (2018). Integration citizen'suggestion system for the urban development: Tangerang city case. Procedia Computer Science, 135, 570-578.

Harriss, J. (2010). Participation and contestation in the governance of Indian cities. Simons Papers in Security and Development, 3, 2-23.

Heeks, R. (2002). Information Systems and Developing Countries: Failure, Success and Local Improvisations. The Information Society, 18(2): 101-112.

Hennen, L. (2002). Impacts of participatory technology assessment on its social environment. In: Joss S., Bellucci, S. (eds.): Participatory technology assessment: European Perspectives. London: University of Westminster (257-275).

Herranz, S., Romero-Gómez, R., Díaz, P., \& Onorati, T. (2014). Multi-view visualizations for emergency communities of volunteers. Journal of $V$ isual Languages \& Computing, 25(6), 981-994.

Jankowski, P., \& Nyerges, T. (2003). Toward a framework for research on geographic information-supported participatory decision-making. URIS A Journal, 15(1), 9-17. 
46 | Technological solutions to encourage civic engagement in urban planning

Kaiser, H. F. (1970). A Second-Generation Little Jiffy. Psychometrika, 35(4), 401-415.

Knight Frank (2012). "The wealth report 2012: a global perspective on prime property and wealth", Available at URL: https://content.knightfrank.com/resources/ knightfrank.com/pdf-documents/thewealthreport2012.pdf

Kingston, R. (2002). Web-based PPGIS in the United Kingdom. In: Craig W.J., Harris T.M., Weiner D. (eds.): Community participation and geographic information systems. London: Taylor \& Francis (101-112).

Kingston, R., Carver, S., Evans, A., \& Turton, I. (2000). Web-based public participation geographical information systems: an aid to local environmental decision-making. Computers, Environment and Urban Systems, 24(2), 109-125.

Krishnaswamy, A. (2012). Strategies and Tools for Effective Public Participation. FORREX Forum for Research and Extension in Natural Resources, Burnaby, Canada, 24525.

Lane, M. B. (2005). Public participation in planning: an intellectual history. Australian Geographer, 36(3), 283-299.

Leena, D., \& Sharma, A. (2007). Government by the people. Analysing 74th Constitutional Amendment Act 1992. Hazards Centre.

Li, S., \& Ma, X. (2006, September). An open source GIS solution for supporting public participation in municipal developments. Proceedings of the ISPRS Commission IV Symposium on Geospatial Databases for Sustainable Development, Goa, (pp. 27-30).

Li, S., Chang, Z., \& Yi, R. (2004, July). GIS-based internet notice board to facilitate public participation in municipal developments. In: Proceedings of the 20th ISPRS Annual Congress, Istanbul (pp. 12-23).

Li, W., Batty, M., \& Goodchild, M. F. (2020). Real-time GIS for smart cities. International Journal of Geographical Information Science, 34(2), 311-324.

Lowndes, V., Pratchett, L., \& Stoker, G. (2001). Trends in public participation: Part $1-$ local government perspectives. Public Administration, 79(1), 205-222.

Lu, X. (2009, December). A GIS-Based integrated platform for E-government application. In: Information Science and Engineering (ICISE), 1st International Conference on GIS, IEEE, ISBN 978-1-4244-4909- 5 (pp. 200-218).

Macintosh, A. (2004). Characterizing e-participation in policy-making. In: Proceedings of the 37th Annual Hawaii International Conference on System Sciences (HICSS-37), Big Island (pp. 5-8).

Malhotra, C. (2016). Public Tools for Open Governance: Review of RTI Act and Social Media in Indian Context. Revue Internationale des Gouvernements Ouverts, 2, 345-359.

Mashelkar, R. A. (2008). Indian science, technology, and society: the changing landscape. Technology in Society, 30(3-4), 299-308.

Menon, S., \& Hartz-Karp, J. (2019). Institutional innovations in public participation for improved local governance and urban sustainability in India. Sustainable Earth, 2(1), 1-19.

Metallo, C., Gesuele, B., Guillamón, M. D., \& Ríos, A. M. (2020). Determinants of public engagement on municipal Facebook pages. The Information Society, 36(3), 147-159. 
Milakovich, M. E. (2010). The Internet and Increased Citizen Participation in Government. JeDEM - EJournal of EDemocracy and Open Government, 2(1), 1-9.

Nallathiga, R. (2014). Capacity Building for Urban Governance: CENA Approach of Andhra Pradesh. Urban India, 34(II), 37-54.

Oh, Y., Jeong, S. H., \& Shin, H. (2019). A Strategy for a Sustainable Local Government: Are Participatory Governments More Efficient, Effective, and Equitable in the Budget Process?. Sustainability, 11(19), 5312.

Rosca, V. I. (2015). Customer attitudes towards buying e-books: Perspectives from a Romanian publishing house. Journal of Community Positive Practices, 15(4), 105-111.

Rosca, V. I. (2018). Read all about it! How mobile phone web access elevates online news consumption. Journal of Community Positive Practices, 18(1), 47-58.

Rowe, G., \& Frewer, L. J. (2000). Public participation methods: a framework for evaluation. Science, Technology, \& Human V alues, 25(1), 3-29.

Satterthwaite, D. (1986). Urbanization and planning in the Third World; spatial perceptions and public participation. Cities, 3(2), 170-171.

Shekgola, M., Maluleka, J., \& Rodrigues, A. (2021). Factors influencing the adoption of free and open-source software for electronic records management by municipalities in Gauteng Province, South Africa. Journal of the South African Society of Archivists, 54, 43-54.

Stake, R. E. (2010). Qualitative Research: Studying How Things Work. New York, NY: Guilford Press.

Ulanowicz, R.E. (1986). Growth and development: Ecosystems phenomenology. New York: Springer.

Wang, X., \& Bryer, T. A. (2013). Assessing the costs of public participation: A case study of two online participation mechanisms. The American Review of Public Administration, 43(2), 179-199.

Warner, C. (2015). Participatory Mapping: a literature review of community-based research and participatory planning. Social Hub for Community Housing, Faculty of Architecture and Town Planning Technion, Cambridge, Massachusetts: Massachusetts Institute of Technology.

Wimmer, M. A., Grimm, R., Jahn, N., \& Hampe, J. F. (2013, September). Mobile participation: exploring mobile tools in e-participation. In: International Conference on Electronic Participation (pp. 1-13). Berlin/Heidelberg: Springer.

Yavetz, G., \& Aharony, N. (2020). Social media in government offices: usage and strategies. Aslib Journal of Information Management, 72(4), 445-462. 